\title{
Financial Inclusion of Fisher Folk in Ramanathapuram District
}

\author{
B. Vimala, K. Alamelu
}

\begin{abstract}
The purpose of this study is to measure the extent of financial inclusion of fisher folk in terms of access and usage. This paper has used primary data. For collecting primary data, a well-structured Interview Schedule has been prepared and administered among the respondents. The sample group consists of 120 sample respondents. The paper uses Paired Sample t Test. 77 per cent of the sample respondents are aware of the different products and services rendered by the banks while 46 per cent of them use the known banking products and services. Comparatively the awareness is more for the traditional products while the same is less for the modern products. The result of the Paired Sample Test reveals that $P$ value is less than 0.05 in awareness and service of usage in financial inclusion of fisher folk. The present paper attempts to find the awareness and usage of financial services of banks by the fisher folks, who avail financial support mostly from the informal sources of finance. By measuring the gap between the awareness and usage of financial services by the fisher folk, the paper may throw useful clues to the policy makers for undertaking segmented initiatives for furthering financial inclusion.
\end{abstract}

Keywords: Indian Fisheries, Financial Inclusion,

Awareness, Usage.

\section{INTRODUCTION}

Financial inclusion is the delivery of financial services at affordable costs to sections of disadvantaged and low-income segments of society. According to Reserve Bank of India (RBI) financial inclusion is the "process of ensuring access to appropriate financial product and services needed by all section of the society in general and vulnerable groups such as weaker sections and low income groups in particular, at an affordable cost in a fair and transparent manner by regulated mainstream institutional players. 'Mangalam' village turnout to be the first village in India where all households were provided banking facilities. In January 2006, as per the direction of the Reserve Bank of India Commercial Banks can make use of the services of agencies such as

Revised Manuscript Received on July 22, 2019

B. Vimala, Department of Commerce, School of Management, Alagappa University, Karaikudi, TamilNadu, India. bosevimala1994@gmail.com

Dr. K. Alamelu, Department of Banking Management, School of Management, Alagappa University, Karaikudi, TamilNadu, India. Email: alakkn@gmail.com
Non-Governmental Organization (NGO), Micro Finance Institutions (MFIs) and other civil society organization in the process of financial inclusion. These intermediaries could be used as Business Facilitators or Business Correspondents by Commercial Banks. Reserve Bank of India's visualization for 2020 is to create a new customer phase of 600 million accounts by leveraging on Information Technology (IT). However illiteracy, lack of savings habits especially among the poor and inadequacy of bank branches in many states hindered the fast pace of financial inclusion.

\section{OBJECTIVES}

a) To study the extent of awareness of various financial services rendered by banks among fisher folk.

b) To examine the level of usage of various financial services rendered by banks by fisher folk.

\section{REVIEW OF LITERATURE}

The cardinal fisheries scientists have increasingly critiqued usually fisheries-management methods (Ludwig et al., 1993; Walters and Parma, 1996; Pitcher et al., 1998 ;). The standard argument supporting the critique is that fisheries populations are stochastic, patchy, and heterogeneous and are linked with highly unpredictable oceanographic processes including upwelling, currents, and wind.(Wilen, E. J., et al., 2002) studied all fisheries-management models incorporate simplifying assumptions about ecological and oceanographic mechanisms that are fundamentally uncertain or stochastic, but exploited fisheries are also subject to equally important uncertainties associated with fisherman behavior. The paper highlighted is an attempt to demonstrate the potential usefulness of economics-based behavioral modeling, with data collected for biological management.

Vimala, B., and Alamelu, K. (2018), studied financial literacy, perceived risk attitudes and investment intensions among women and found that women attained a moderate score on the risk attitudes and investment intentions. The study found that age, monthly income of the family, and educational qualifications have significant association with the level of financial literacy of the respondents.

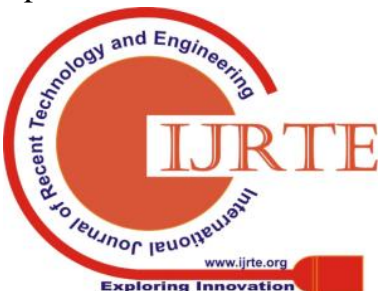


Rangarajan, C. (2014), his stated that report on the committee number of poor in India has been much higher in 2011-12 at $29.5 \%$ of the population. He highlighted the report Rs. 47 for the daily per capita expenditure for the urban poor and at pegged at Rs. 32 for rural poor. In the year 2009-10, about lifted out of poverty 91.6 million people as compared to 454.6 million poor in the year 2009-10. Finally the poverty line on the average monthly per capita expenditure is pegged at Rs. 972 for rural India and Rs. 1407 for urban India.

\section{HYPOTHESES}

$\mathbf{H}_{\mathbf{0}}$ : There is no significant difference between the level of awareness and usage of financial services.

\section{Methodology}

The study will based on the primary data collected through interview method by administering a pre-structured from the fisherfolk in Ramanathapuram District. The sample size is 120.

\section{SCOPE OF THE STUDY}

The study is confined to selected fishermen workers of Ramanathapuram District. The study will help to understand the extent of financial inclusion among fisherfolk. The study will also find out the awareness of fishermen towards formal financial system. No study has been conducted in 'Financial Inclusion of Fisher Folk in Ramanathapuram District', which help to identify the problems and arriving suggestions to resolve the identified problems.

\section{INDIAN FISHERIES}

Indian fisheries and aquaculture occupy an important place in the Indian economy. They provide nutritional security, livelihood support and gainful employment to more than 14 million people, and contribute to agricultural exports. Diverse resources ranging from deep seas to lakes in the mountains and more than $10 \%$ of the global biodiversity in terms of fish and shellfish species, the country has shown continuous and sustained increments in fish production since independence. The total fish production during 2017-18 is stands at 12.60 million metric tonnes, and constitutes about 6.3 percentage of the global fish production and its share in the GDP is $1.1 \%$.

Fisherman or fisher is indiscriminate fishing, by catch and overfishing, it seems like merely putting a net in the water will guarantee a fisherman his catch. Fisher fold know something about the marine environment that other people don't. Is her folk's minds linked in knowledge, occupation and identity.

\begin{tabular}{|l|l|}
\hline \multicolumn{2}{|c|}{ Indian Fisheries } \\
\hline Global position & $\begin{array}{l}3^{\text {rd }} \text { in Fisheries } \\
2^{\text {nd }} \text { in Aquaculture }\end{array}$ \\
\hline Contribution of Fisheries to GDP (\%) & 0.91 \\
\hline Contribution to Agril. GDP (\%) & 5.23 \\
\hline Per capita fish availability (Kg.) & 9.0 \\
\hline Annual Export earnings (Rs. In Crore) & $45,106.89$ \\
\hline Employment in sector (million) & 14.0 \\
\hline \multicolumn{1}{|c|}{ Some Facts } & 6.4 million metric tone (mmt) \\
\hline Present fish production & 3.4 mmt \\
\hline Inland & 3.0 mmt \\
\hline Marine & 8.4 \\
\hline Potential fish production & 21000 million fry \\
\hline Fish seed production & 1070 \\
\hline Hatcheries & 422 \\
\hline FFDA & 39 \\
\hline BFDA & \\
\hline
\end{tabular}

Source: NFDB, (2017) 


\section{DATA ANALYSIS AND INTERPRETAION}

Table- II: Demographic Profile

\begin{tabular}{|c|c|c|c|}
\hline Variable & Frequency & Percent & Cumulative Percent \\
\hline \multicolumn{4}{|l|}{ Gender } \\
\hline Male & 100 & 83 & 83 \\
\hline Female & 20 & 17 & 100 \\
\hline Total & 120 & 100 & \\
\hline \multicolumn{4}{|l|}{ Age } \\
\hline Below 20 Years & 15 & 13 & 13 \\
\hline 20-30 Years & 19 & 16 & 28 \\
\hline $30-40$ Years & 30 & 25 & 53 \\
\hline 40-50 Years & 35 & 29 & 83 \\
\hline Above 50 Years & 21 & 18 & 100 \\
\hline Total & 120 & 100 & \\
\hline \multicolumn{4}{|l|}{ Marital Status } \\
\hline Married & 96 & 80 & 80 \\
\hline Single & 24 & 20 & 100 \\
\hline Total & 120 & 100 & \\
\hline \multicolumn{4}{|l|}{ Educational Qualification } \\
\hline Illiterate & 26 & 22 & 22 \\
\hline $8^{\text {th }}$ Standard & 49 & 41 & 63 \\
\hline SSLC & 30 & 25 & 88 \\
\hline HSC & 15 & 13 & 100 \\
\hline Total & 120 & 100 & \\
\hline \multicolumn{4}{|l|}{ Monthly Income } \\
\hline Less than Rs.25,000 & 34 & 28 & 28 \\
\hline Rs. 25,000 to 50,000 & 43 & 36 & 64 \\
\hline More than Rs.50,000 & 43 & 36 & 100 \\
\hline Total & 120 & 100 & \\
\hline
\end{tabular}

\section{Source: Researcher's Computation}

The fisherman personal profile of the sample respondents has been tabulated in the above table. Among 120 fisherman responded in the survey, 83 per cent of the fisherman belonged to male category and only 17 per cent are females with regard to age of the sample respondents, 13 per cent belongs to the age group below 20 years, 16 per cent of them belongs to the age group of 20-30 years, 25 per cent belongs to the age group of 30-40 years, 29 per cent of them belongs to 40-50 years and only 18 per cent belongs to the age group of the above.

Therefore, majority of the fisherman belongs to the age upto 50. 80 per cent are married, and 20 per cent are unmarried. Therefore, it is concluded that majority of the respondents are married. Regarding educational qualification 41 per cent of the completed $8^{\text {th }}$ standard. The respondents' family mostly have the monthly income of less 
than Rs.25, 000, which is about 34 samples followed by 43 respondents have the monthly income of Rs.25,000 to
Rs.50,000, and 43 respondents have the income of more than

Rs. 50,000

Table- III: Awareness of Banking Products and Services

\begin{tabular}{|l|c|c|c|c|c|c|c|}
\hline \multirow{2}{*}{ Banking services } & \multicolumn{3}{c|}{ Awareness } & \multicolumn{3}{c|}{ Service of Usage } & \multirow{2}{*}{ Usage } \\
\cline { 2 - 7 } & Yes & No & Gap & Yes & No & \% & \multirow{2}{*}{} \\
\hline Pass Book & 113 & 7 & 94 & 88 & 32 & 73 & 85 \\
\hline Cash Withdrawal & 110 & 10 & 92 & 93 & 27 & 78 & 57 \\
\hline Deposit & 104 & 16 & 87 & 60 & 60 & 50 & 59 \\
\hline ATM Card & 99 & 21 & 83 & 89 & 31 & 74 & 89 \\
\hline Loans & 104 & 16 & 87 & 62 & 58 & 52 & 60 \\
\hline Jewel Loan & 96 & 24 & 80 & 46 & 74 & 38 & 48 \\
\hline Housing Loan & 85 & 35 & 71 & 30 & 90 & 25 & 35 \\
\hline Smart Card Average & 20 & 100 & 17 & 9 & 111 & 8 & 47 \\
\hline Personal Loan & 103 & 17 & 86 & 20 & 100 & 17 & 20 \\
\hline & $\mathbf{9 3}$ & $\mathbf{2 7}$ & $\mathbf{7 7}$ & $\mathbf{5 5}$ & $\mathbf{6 5}$ & $\mathbf{4 6}$ & $\mathbf{5 8}$ \\
\hline
\end{tabular}

Source: Researcher's Computation

Table- IV: Paired Samples Statistics for the Usage Gap

\begin{tabular}{|l|l|c|c|c|c|}
\hline \multicolumn{9}{|c|}{ Paired Samples Statistics } \\
\hline \multicolumn{2}{|c|}{} & Mean & N & Std. Deviation & Std. Error Mean \\
\hline \multirow{2}{*}{ Pair 1 } & Awareness & 92.6667 & 9 & 28.43413 & 9.47804 \\
\cline { 2 - 6 } & Service of usage & 55.2222 & 9 & 31.24411 & 10.41470 \\
\hline
\end{tabular}

Source: Researcher's Computation

Table- V: Paired Samples Correlations

\begin{tabular}{|l|c|c|c|}
\hline \multicolumn{3}{|c|}{ Paired Samples Correlations } \\
\hline & N & Correlation & Sig. \\
\hline Pair 1awareness\& Service of Usage & 9 & 0.679 & 0.044 \\
\hline
\end{tabular}

Source: Researcher's Computation

Table- VI: Paired Differences

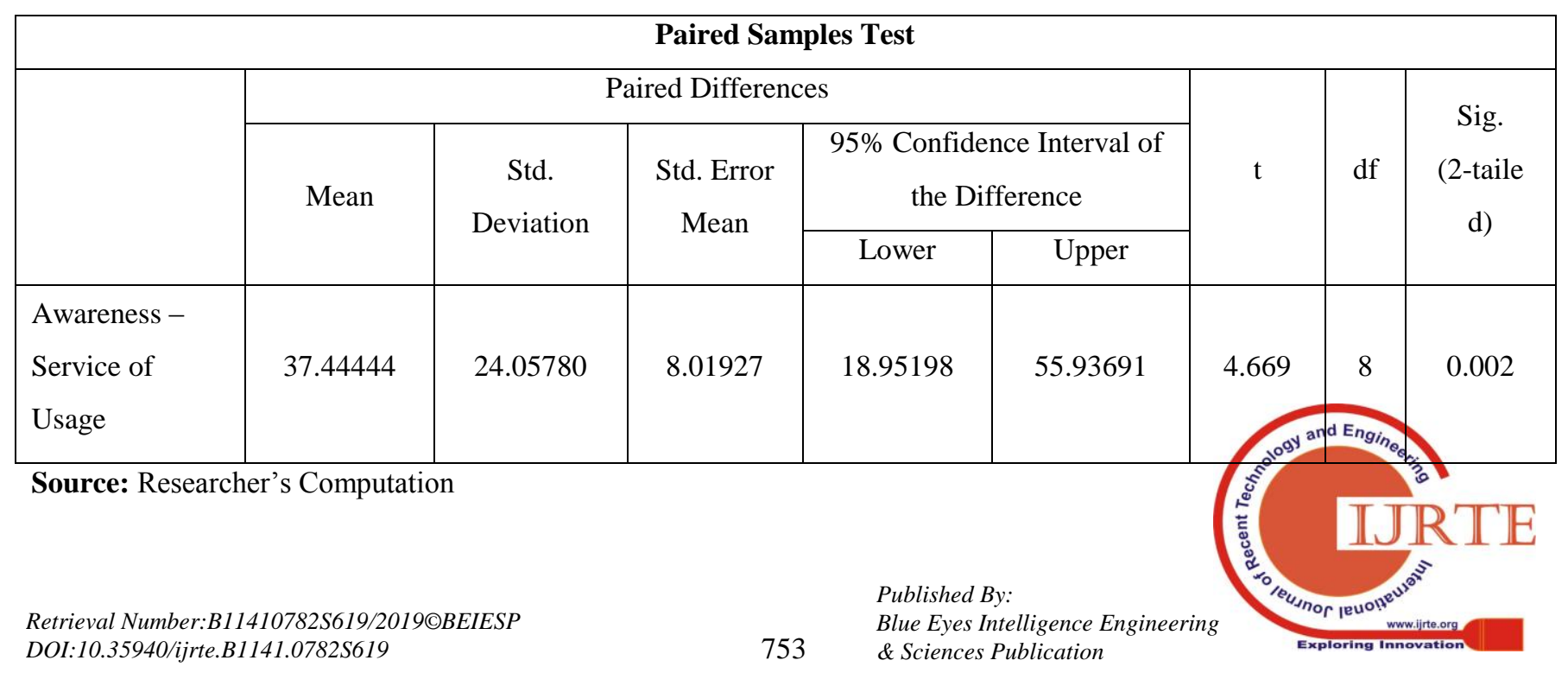




\section{RESULT AND DISCUSSION}

On an average, 77 per cent of the sample respondents are aware of the different products and services rendered by the banks while 46 per cent of them using the known banking products and services. Comparatively the awareness is more for the traditional products while the same is less for the modern products. The sample respondents are fully aware of the basic but vital products like the usage of Pass book with the usage gap $(94 \%, 73 \%, 78 \%)$, Cash withdrawal (92\%, $78 \%, 85 \%)$, Deposit $(87 \%, 50 \%, 57 \%)$, ATM card $(83 \%$, $74 \%, 89)$, Loans $(87 \%, 52 \%, 60 \%)$, Jewel loan $(80 \%, 38 \%$, $48)$, Housing loan $(71 \%, 25 \%, 35 \%)$, Smart card $(17 \%, 8 \%$, $47 \%)$ and Personal loan $(86 \%, 17 \%, 20 \%)$. The ignorance of Smart card is mainly because the scheme is meant for farmers and not to Fisher Folks. Hence, it is apparent that the sample Fisher Folk are much aware of the traditional products and services and the awareness of modern banking products is comparatively low among the Fisher Folk in Ramanathapuram District.

The usage gap between the awareness and application of banking products and services is tested through Paired Samples Statistics which is presented and discussed as below. The mean for the awareness of banking products and services is 92.67 while the same for the application of banking products and services is 55.22 and the standard deviation is 28.43 and 31.24 respectively for awareness and application of banking products and services. It is inferred that though the sample group aware of the banking products and services, they hesitate to use them spontaneously.

The result of the Paired Samples Test (Paired Differences) depicted in table 6 reveals that $\mathbf{P}$ value is less than 0.05 in awareness and service of usage in financial inclusion of fisher folk. So the null hypothesis is not accepted at 5 per cent level of significance.

\section{CONCLUSION}

Thus, it can be concluded that the level of awareness of financial services among fishermen is appreciable which may be attributed to the initiatives of the financial inclusion taken by the Reserve Bank of India and the Government of India. However, the usage gap in availing the service still exists. Efforts are to be made to encourage the usage of such service by the fisher folk in order to relive them from the clutches of money lenders.

\section{REFERENCES}

1. Ludwig, D., Hilborn, R. and Walters, C. (1993). Uncertainty, resource exploitation, and conservation: lessons from history. Science 260, pp. 17-18.

2. NFDB [National Fisheries Development Board], (2017). NFDB home page [online].available:nfdb.gov.inland-indian-fisheries.htm[ 24 March 2017].

3. Pitcher, T. J., Hart, P. J. B., and Pauly, eds. (1998). Reinventing Fisheries Management. Chapman \& Hall, London. Pp. 435.

4. Rangarajan, C. (2014). Dr. C Rangarajan Committee on Poverty presented its report to Union Government. Ministry of Finance, Government of India.

5. Vimala, B., and Alamelu, K. (2018). Financial literacy, perceived risk attitudes and investment intentions among women. PARIPEX - Indian Journal of Research. 7(11), pp. 55-57.

6. Walters, and Parma, A (1996). Fixed exploitation rate strategies for coping with the effects of climate change. Can. J. Fish. Aquat. Science 53, pp. 148-158.

7. Wilen, J. E., Smith, M. D., Lockwood, D., and Botsford, L. W (2002). Avoiding Surprises: Incorporating Fisherman Behavior into Management Models. Bulletin of Marine Science. 70(2), pp. 553-575. 
Financial Inclusion of Fisher Folk in Ramanathapuram District

\section{AUTHORS PROFILE}

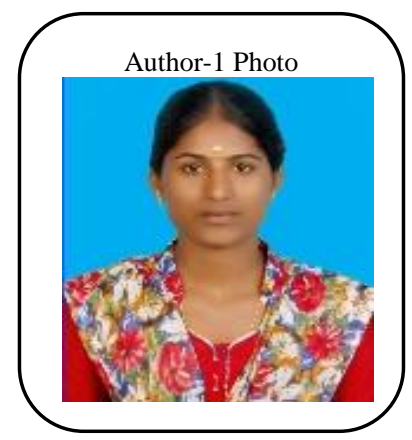

Ms. B. VIMALA is a PG in Commerce, and is currently pursuing Ph.D. (Full-time) under the ICSSR Doctoral Fellowship Programme.

Her areas of interest are Financial Inclusion and Gender Studies.

She has published 10 articles in various Journals.

She can be reached at bosevimala1994@gmail.com

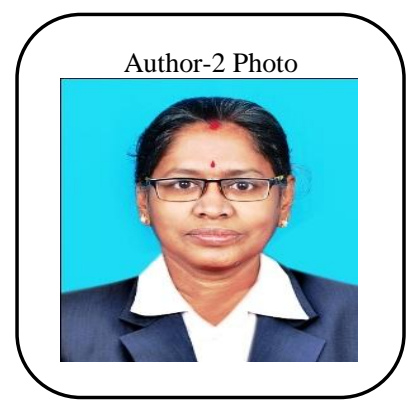

Dr. K. ALAMELU is a professor of Banking Management and Director i/c, Directorate of Distance Education, Alagappa University, Karaikudi.

She has published more than 25 articles in reputed Journal like 'The Analyst', The ICFAI Journal of Risk \& Insurance', and 'The Indian Economic Journal'. She specializes in Financial Inclusion and Credit Management.

She can be contacted at alakkn@gmail.com 